\title{
MULTIPLICATION, ROOTING IN VITRO, AND ACCLIMATIZATION OF Brassavola tuberculata Hook. (ORCHIDACEAE), AN ORCHID ENDEMIC TO THE BRAZILIAN ATLANTIC RAINFOREST
}

\author{
MULTIPLICAÇÃO, ENRAIZAMENTO in vitro E ACLIMATIZAÇÃO DE Brassavola \\ tuberculata Hook (ORCHIDACEAE), UMA ORQUÍDEA ENDÊMICA DA MATA \\ ATLÂNTICA BRASILEIRA
}

\author{
Liana Hilda Golin MENGARDA ${ }^{1}$; Geovana Poton Arcobeli COLA ${ }^{1}$; \\ Stefanie Cristina de OLIVEIRA1 ${ }^{1}$; Allan Rocha de FREITAS ${ }^{1}$ \\ 1. Programa de Pós-graduação em Produção Vegetal - Universidade Federal do Espírito Santo, CCA, Alegre, ES, Brasil. \\ liana_ya@yahoo.com.br.
}

\begin{abstract}
The objective of this study was to promote the establishment of an in vitro culture of Brassavola tuberculata, testing different concentrations of naphthalene acetic acid (NAA) and 6-benzylaminopurine (BAP) on multiplication and rooting, evaluating different substrates during acclimatization, as well as the effect of in vitro treatments. After germination, the seedlings of B. tuberculata were subjected to culture on MS medium supplemented with different concentrations of NAA and BAP, and multiplication and rooting were assessed. During acclimatization, different substrates were tested: S1, Plantmax ${ }^{\circledR}$ and vermiculite (1: 1); S2, Plantmax ${ }^{\circledR}$ and grit (1: 1); and S3, dust fern. Also the effect of the in vitro culture treatments was evaluated: T1, control; T5, $(2.5 \mu \mathrm{M}$ NAA $+5 \mu \mathrm{M}$ BAP $)$; and T7, $(5 \mu \mathrm{M}$ NAA + $0 \mu \mathrm{M}$ BAP). The favorable balance of cytokinins promoted by treatment T5 yielded the largest number of shoots and leaves in B. tuberculata. The greatest length of leaves and roots, and highest root number were observed in the treatment T7, favored by the presence of auxin. This treatment had a positive effect with respect to plant acclimatization: T7 associated with substrate S1 provided the most suitable conditions for acclimatization of seedlings of B. tuberculata, providing greater number and length of leaves, and high survival rate.
\end{abstract}

KEYWORDS: 6-benzylaminopurine. In vitro establishment. Naphthalene acetic acid. Substrates. Tissue culture.

\section{INTRODUCTION}

Orchids are among the most appreciated and most commercially valuable ornamental plants. Nevertheless, many species are at risk of extinction owing to the destruction of their habitat and predatory extractivism (COLOMBO et al., 2004; ROBERTS and DIXON, 2008). Brassavola tuberculata Hook is an epiphytic species with very wide occurrence, whose limits as a species are still considered indeterminate due to the specie's variability (HERMANN et al., 2011). As seen in most species of Orchidaceae, B. tuberculata Hook has tiny seeds which, under natural conditions, germinate through association with mycorrhizal fungi that provide the required nutrients. Even so, the natural germination is very difficult, with rates as low as 5\% (RASMUSSEN, 2002).

One of the main advantages of in vitro germination in orchids is the achievement of higher germination rates compared with natural conditions. Furthermore, it serves as an in vitro conservation method, which contributes to reducing the risk of extinction (UNEMOTO et al., 2007; FERREIRA and SUZUKI, 2008).
The formulation of the culture medium is essential for the development of the explant, whereby the presence of necessary constituents (minerals, vitamins and growth regulators) stimulates proliferation, rooting and growth (FARIA et al., 2002). According to Shimura and Koda (2004), growth regulators such as auxins and cytokinins influence the development of orchid explants. For Cymbidium giganteum and four varieties of Phalaenopsis cultivated in vitro, the use of naphthalene acetic acid (NAA) and 6benzylaminopurine (BAP) provided significant responses in the development of shoots (NAGARAJU and PARTHASARATHY, 1999; PARK et al., 2002; HOSSAIN, 2008; HOSSAIN et al., 2009).

Another crucial step in the in vitro cultivation of orchids is acclimatization. During this phase, the loss of plants can be very high, constituting a limiting factor in the multiplication process. In particular, for orchid seedlings germinated in vitro, in an asymbiotic manner, it becomes necessary to find suitable substrates that permit the vegetative establishment of these seedlings (COLOMBO et al., 2005). 
However, due to the restrictions in natural propagation exhibited by orchids, studies on their propagation process are important, not only to improve their production, but also to collaborate with their preservation. Nevertheless, no published reports are available on in and ex vitro establishment of B. tuberculata Hook. Therefore, the objective of the present research was to promote the establishment of cultivation in this species, testing different concentrations of NAA and BAP on multiplication and rooting in vitro, and evaluating different substrates, as well as the effects of in vitro cultivation treatments, on acclimatization.

\section{MATERIAL AND METHODS}

A capsule containing seeds of $B$. tuberculata Hook (Orchidaceae) was collected from a private plant nursery in the city of Alegre - ES, Brazil. The capsule was disinfected by immersion in $70 \%$ ethanol $\left(\right.$ Merck $\left.^{\circledR}\right)$ for $15 \mathrm{~min}$, followed by $2.5 \%$ sodium hypochlorite solution for $20 \mathrm{~min}$, and rinsing three times with autoclaved $\mathrm{dH}_{2} \mathrm{O}$.
After the disinfection step, performed under laminar flow hood, seeding was carried out. Approximately $0.01 \mathrm{~g}$ of seeds were placed onto Petri dishes $(90 \times 15 \mathrm{~mm})$ containing $30 \mathrm{~mL}$ of Murashige and Skoog (MS) medium (MURASHIGE; SKOOG, 1962) supplemented with $30 \mathrm{~g} \mathrm{~L}^{-1}$ sucrose, and $7.0 \mathrm{~g} \mathrm{~L}^{-1}$ agar (Vetec $\AA$ ); the $\mathrm{pH}$ was adjusted to 5.7. This culture was maintained at $25 \pm 11^{\circ} \mathrm{C}$ under $16 / 8 \mathrm{~h}$ light/dark regime, with 36 $\mu \mathrm{mol} \mathrm{m} \mathrm{s}^{-2}$ light radiation.

The germination was characterized by the formation of a protocorm, a tuberiform structure characteristic of the germination of orchid seeds (KRAUS et al., 2006).

After 90 days, the seedlings of $B$. tuberculata Hook germinated in vitro, showing approximately $1 \mathrm{~cm}$ in length and three leaves, were transferred to glass jars containing $30 \mathrm{~mL}$ of $\mathrm{MS}$ medium supplemented with different concentrations of naphthalene acetic acid (NAA) and 6benzylaminopurine (BAP) (Table 1).

Table 1. MS culture medium supplemented with different concentrations of NAA and BAP.

\begin{tabular}{ccc}
\hline TREATMENTS & ANA $(\mu \mathrm{M})$ & BAP $(\mu \mathrm{M})$ \\
\hline T1 & 0.0 & 0.0 \\
T2 & 0.0 & 5.0 \\
T3 & 0.0 & 10.0 \\
T4 & 2.5 & 0.0 \\
T5 & 2.5 & 5.0 \\
T6 & 2.5 & 10.0 \\
T7 & 5.0 & 0.0 \\
T8 & 5.0 & 5.0 \\
T9 & 5.0 & 10.0 \\
\hline
\end{tabular}

The seedlings were maintained under the in vitro germination conditions described above. After 30, 60 and 90 days, the average number of shoots, leaves and roots and the length of the longest leaf $(\mathrm{cm})$ and longest root $(\mathrm{cm})$ were assessed.

For the multiplication and rooting in vitro, a completely randomized design was adopted, with nine treatments and ten replicates per treatment. Each replication consisted of a glass jar containing ten seedlings. The results were subjected to analysis of variance, and means were compared by the ScottKnott test at 5\% significance level (THE R FOUNDATION FOR STATISTICAL COMPUTING PLATFORM 2014).
Two experiments were conducted during acclimatization, in order to: (1) determine the most suitable substrate; and (2) verify the influence of treatments $\mathrm{T} 1, \mathrm{~T} 5$ and $\mathrm{T} 7$ on acclimatization, as described below:

1 - Substrates for acclimatization: T1 seedlings were removed from the culture medium and transferred into pots containing different substrates: S1, Plantmax ${ }^{\circledR}$ and vermiculite (1: 1); S2, Plantmax ${ }^{\circledR}$ and sand (1: 1); and S3, dust fern. The plants were maintained for 15 days in a growth chamber, covered with plastic bags, at $25 \pm 1{ }^{\circ} \mathrm{C}$ and $16 / 8 \mathrm{~h}$ light/dark regime, with $36 \mu \mathrm{mol} \mathrm{m} \mathrm{m}^{-2} \mathrm{~s}^{-1}$ light radiation. After this period, the seedlings were transferred to greenhouse. After 90 days, the 
survival rate, number of leaves and length of the largest leaf $(\mathrm{cm})$ were assessed.'

2 - Effect of treatments on acclimatization: Seedlings from the treatments $\mathrm{T} 1, \mathrm{~T} 5$ and $\mathrm{T} 7$ were acclimatized using substrate S1 (Plantmax ${ }^{\circledR}$ and vermiculite) in the ratio $1: 1$. The seedlings went through the same process described above. At 60 days, the survival rate was evaluated, as well as the number of leaves and length of the largest leaf $(\mathrm{cm})$.

For the acclimatization stage a completely randomized experimental design was adopted with three treatments and ten replicates per treatment. Each replication consisted of one seedling into a plastic cup containing $50 \mathrm{~mL}$ of substrate. The results were subjected to analysis of variance, and the means were compared by Tukey test at $5 \%$ significance level (THE R FOUNDATION FOR STATISTICAL COMPUTING PLATFORM 2014).

\section{RESULTS AND DISCUSSION}

After 30, 60 and 90 days of in vitro culture under different treatments, it was observed that the addition of plant growth regulators to the culture medium had a differential effect on each variable analyzed (Figure 1 and 2). At the 90-day assessment, the highest averages for shoot number were observed in treatments $\mathrm{T} 3(0 \mu \mathrm{M}$ NAA +10 $\mu \mathrm{M}$ BAP $)$ and $\mathrm{T} 5(2.5 \mu \mathrm{M} \mathrm{NA}+5 \mu \mathrm{M}$ BAP $)$ (Figure 1A). Treatment T5 also stood out at the 30and 60-day evaluations.
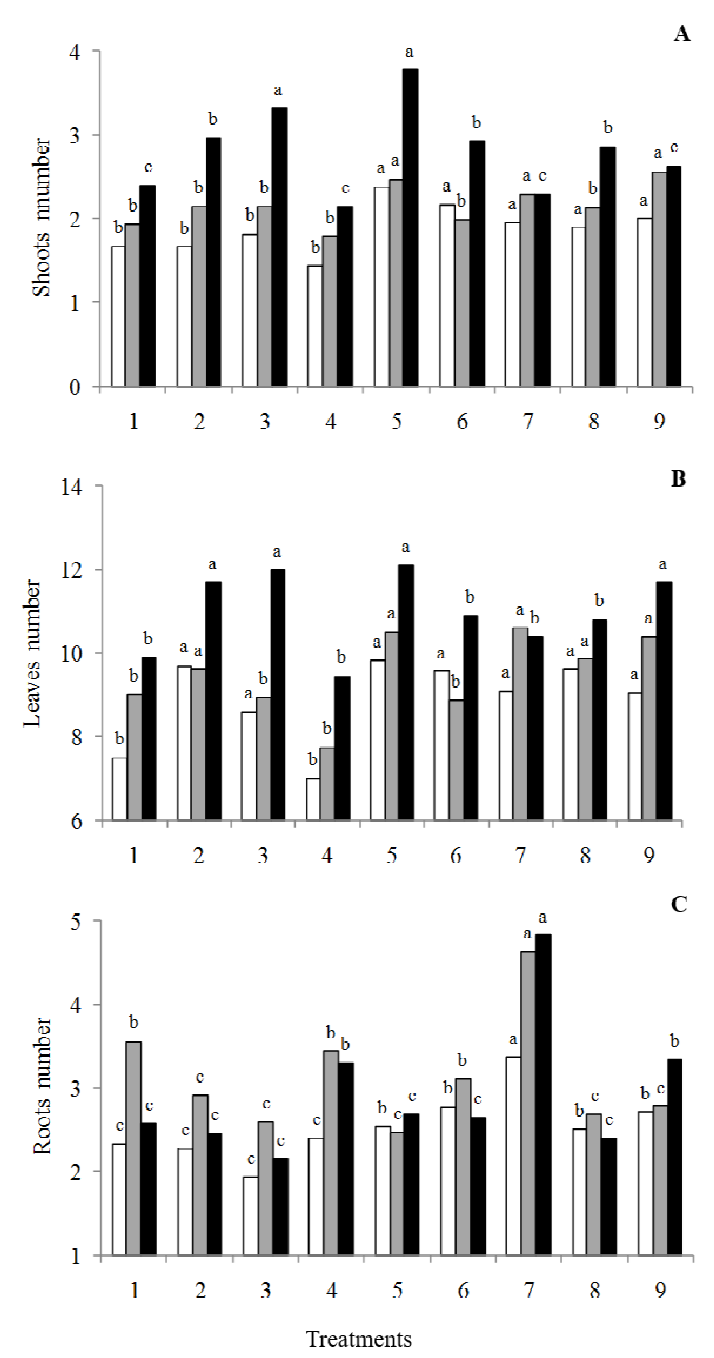

Figure 1. Effect of NAA and BAP combinations in the multiplication of B. tuberculata: A - number of shoots; $\mathrm{B}$ - number of leaves; $\mathrm{C}$ - number of roots. Assessment at 30 (white bars), 60 (gray bars) and 90 days (black bars). Mean values with the same letter between treatments (for each evaluation period) are grouped by the Scott-Knott test at $5 \%$ probability $(\mathrm{n}=10)$. 


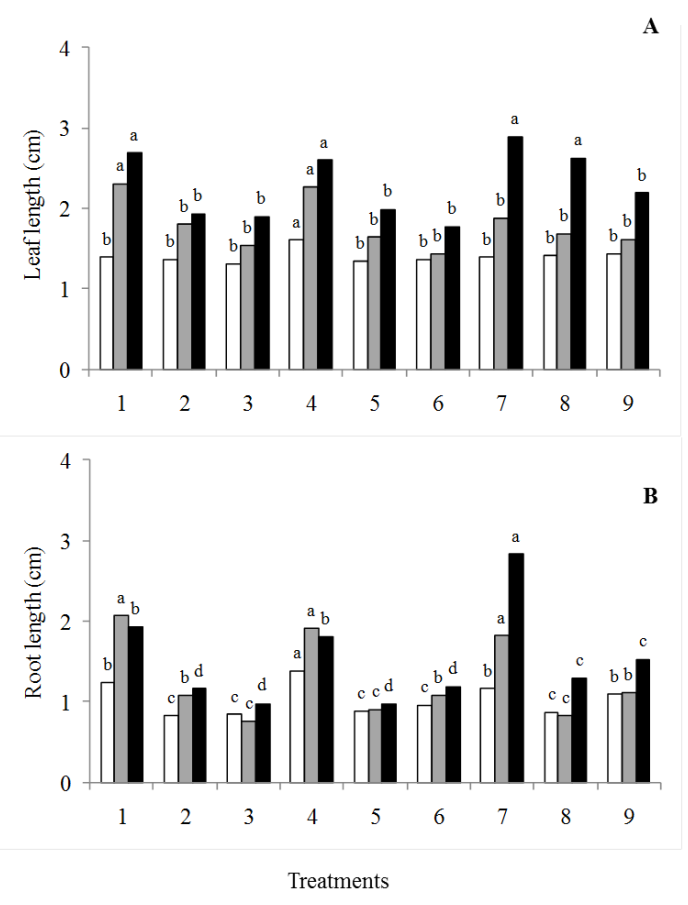

Figure 2. Effect of NAA and BAP combinations on the growth of B. tuberculata: A - leaf length; B- root length. Assessment at 30 (white bars), 60 (gray bars) and 90 days (black bars). Mean values with the same letter between treatments (for each evaluation period) are grouped by the Scott-Knott test at $5 \%$ probability $(\mathrm{n}=10)$.

The different combinations of auxin/cytokinin showed that increased formation of buds occurred in the absence or at low concentrations of NAA in combination with BAP. The same combination was show to increase the number of formed leaves, whereby the use of high concentrations of BAP in treatments T2, T3, T5 and T9 showed significantly higher means (Figure 1B).

$\mathrm{BAP}$, as well as most cytokinins derived from adenine (aminopurine), has a key role in differentiation and plant regeneration in most species (CASTRO et al., 2002). For the hybrid Blc. Owen Holmes Ponkan x Brassavola digbiana no. 2 (GIATTI; LIMA, 2007), the combination favorable to cytokinin ( $\downarrow$ auxin/ $\uparrow$ cytokinin) proved suitable for multiplication of shoots and leaf formation, just as attested by the results obtained for $B$. tuberculata (Figure 1A and B). The same combination has also been suggested for the species Cymbidium giganteum (HOSSAIN et al., 2010), Cymbidium (PATHAK et al., 2001), and Cattleya aurantiaca (PIERIK; STEEGMANS, 1972).

Analysis of the average number of roots (Figure 1C) and longest root length (Figure 2B) showed a higher mean value for the treatment $\mathrm{T} 7$ (5 $\mu \mathrm{M}$ NAA + BAP $0 \mu \mathrm{M})$. Similar results were observed for the genera Dendrobium and Oncidium, in which the presence of NAA provided the highest number of roots (TALUKDER et al., 2003; SORACE et al., 2007).

Auxins and cytokinins are the main hormones involved in regulating plant growth and development, especially in the processes that determine the architecture of the roots and favor rooting. Auxins in particular have a positive effect on the early occurrence of root differentiation from cells (LASKOWSKI et al., 2008; BIELACH et al., 2012). As shown in this work for the species $B$. tuberculata, rooting was observed in the presence of $5 \mu \mathrm{M}$ NAA auxin in the culture medium.

In the analysis of leaf length, treatments $\mathrm{T} 1$ (control), T4, T7 and T8 were statistically similar at day 90 (Figure 2A). Considering the response from the control treatment, it is evident that, despite presenting a small seed, with structure devoid of nutritional reserve, when germinated under ideal conditions, B. tuberculata can develop physiological mechanisms that synthesize hormones responsible for the regulation of plant growth as regards leaf length.

Treatment T7, besides showing higher average for root number and length, also stood out among the top averages for leaf length (Figure 2). The presence of NAA promotes, thus, a better response to the elongation of the leaf.

However, the treatments with BAP concentrations higher than NAA concentrations 
presented smaller leaf length. In some cases, the increase in the concentration of cytokinin in the culture medium may cause slower development, and decrease the length of shoot leaves (GRATTAPAGLIA; MACHADO, 1998; ERIG et al., 2002; NICIOLI et al., 2008).

Thus, regarding the 90 days of culture in vitro, it was concluded that the balance favoring cytokinins offered by treatment T5 (2.5 $\mu \mathrm{M}$ NAA + $5 \mu \mathrm{M}$ BAP) promoted greater number of shoots and leaves in $B$. tuberculata. The greatest length of leaves and roots as well as increased root number were seen in treatment T7 $(5 \mu \mathrm{M}$ NAA $+0 \mu \mathrm{M}$ BAP), favorable to auxin (Figure 1, 2 and 3C).

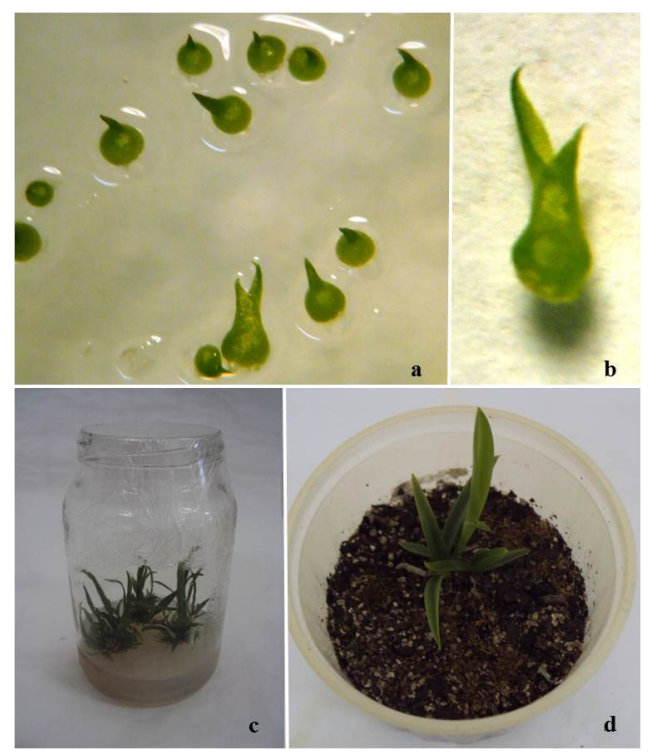

Figure 3. Establishment and multiplication in vitro, and acclimatization of B. tuberculata: A - seed germination and establishment in vitro on MS medium for 60 days; B - protocorm with a pair of leaves in detail; $\mathrm{C}$ - multiplication and rooting of seedlings at 90 days on MS medium supplemented with $5 \mu \mathrm{M}$ NAA + BAP $0 \mu \mathrm{M}$ (treatment 7); D - seedlings from treatment 7 after 60 days of acclimatization in substrate Plantmax ${ }^{\circledR}$ and vermiculite $(1: 1)$.

In the acclimatization phase, the mean $\mathrm{S} 1$, $\mathrm{S} 2$ and $\mathrm{S} 3$ treatments for the number of leaves (NL), length of the longest leaf (LL), and survival rate (S) were statistically equal by Tukey test at $5 \%$ probability. However, S1 had $100 \%$ survival (Table 2).

Table 2. Effect of different substrates on the growth of $B$. tuberculata: NL- number of leaves; LLaverage length of the longest leaf; $S$ - survival percentage assessed at 90 days.

\begin{tabular}{lccc} 
Substrates & NL & LL $(\mathrm{cm})$ & S (\%) \\
\hline S1 & $4.35 \mathrm{a}$ & $3.24 \mathrm{a}$ & $100.00 \mathrm{a}$ \\
S2 & $4.20 \mathrm{a}$ & $2.32 \mathrm{a}$ & $95.00 \mathrm{a}$ \\
$\mathrm{S} 3$ & $5.35 \mathrm{a}$ & $2.48 \mathrm{a}$ & $95.00 \mathrm{a}$ \\
\hline CV\% & 20.02 & 27.31 & 9.44 \\
\hline
\end{tabular}

${ }^{*}$ Means with the same letters in columns are not statistically different by Tukey test at $5 \%$ probability $(\mathrm{n}=10) . \mathrm{S} 1=\mathrm{Plantmax}$ and vermiculite (1: 1); S2 = Plantmax and sand (1:1); S3 = dust fern. CV\% = coefficient of variation of average.

Regarding the evaluation of treatment effects, the treatment $\mathrm{T} 7$ stood out with the highest averages for leaf number and length (NL and LL) and survival (S), though not statistically different from T1 (Table 3). 
Table 3. Effect of treatments on acclimatization of B. tuberculata: NL - number of leaves; LL - average length of the longest leaf; $\mathrm{S}$ - survival percentage assessed at 60 days.

\begin{tabular}{lccc} 
Treatments & NL & LL $(\mathrm{cm})$ & $\mathrm{S}(\%)$ \\
\hline T1 (S1) & $2.70 \mathrm{ab}$ & $0.72 \mathrm{~b}$ & $70 \mathrm{ab}$ \\
T5 (S1) & $1.12 \mathrm{~b}$ & $1.22 \mathrm{~b}$ & $50 \mathrm{~b}$ \\
T7 (S1) & $3.35 \mathrm{a}$ & $2.38 \mathrm{a}$ & $95 \mathrm{a}$ \\
\hline CV\% & 42.35 & 27.83 & 27.76
\end{tabular}

${ }^{*} \mathrm{~T} 1$ (control); T5 $=2.5 \mu \mathrm{M}$ of NAA + BAP $0 \mu \mathrm{M} ; \mathrm{T} 7=5 \mu \mathrm{M}$ of NAA + BAP $0 \mu \mathrm{M} ; \mathrm{S} 1=$ Plantmax and vermiculite $(1: 1)$. CV\% $=$ Coefficient of variation of average. Means with the same letters in columns are not statistically different by Tukey test at $5 \%$ probability $(\mathrm{n}=10)$.

B. tuberculata is an epiphytic orchid that depends primarily on the development and aeration of its roots. Thus, in vitro rooting is a prerequisite for adaptation of the seedlings to the ex vitro environment (GANTAIT et al., 2009). In previous evaluations, $\mathrm{T} 7$ was the treatment with the highest number and length of roots (Figure $3 \mathrm{C}$ and D). According to Moraes et al. (2002), in study regarding root development in vitro, the combination of vermiculite and Plantmax ${ }^{\circledR}$ contributed to a good root aeration, and thus to the seedling development.

For other species of the orchid family, the use of tree fern fiber has been reported for the acclimatization of seedlings of Dendrobium nobile (MORAES et al., 2002), and sand coarse + Plantmax ${ }^{\circledR}$ for Epidendrum ibaguense Lindl. (MENEGUCE et al., 2004) propagated in vitro. Although many studies indicate the use of tree fern fiber as substrate, due to providing better physiological conditions for seedling acclimatization, its extraction is forbidden in nature. For this reason, despite its good qualities, an alternative must be found for this substrate (DEMATTÊ and DEMATTÊ, 1996).

In the present work, the previous conditions of in vitro culture which promoted greater number and length of roots, i.e., MS medium supplemented with $5 \mu \mathrm{M}$ NAA + BAP $0 \mu \mathrm{M}$ (T7), associated with the substrate Plantmax ${ }^{\circledR}$ and vermiculite (1:1) (S1), were best for acclimatization of seedlings of $B$. tuberculata propagated in vitro (Figure 1D). Moreover, they provided increased length of leaves and high survival rate.

\section{ACKNOWLEDGEMENTS}

The authors are grateful to the Laboratory of Plant Tissue Culture and the Laboratory of Seed Analyses at the Department of Plant Production of the Center of Agricultural Sciences- UFES. We thank Mr. Dyego Costa Vieira for providing the orchid seeds used in the development of this study.

RESUMO: Objetivou-se, com este trabalho, promover o estabelecimento do cultivo in vitro de Brassavola tuberculata, testando diferentes concentrações de ANA e BAP na multiplicação e no enraizamento, e avaliar diferentes substratos e o efeito dos tratamentos de cultivo in vitro na aclimatização. Após a germinação das sementes, as plântulas de B. tuberculata foram submetidas ao cultivo em meio MS suplementado com diferentes concentrações de ácido naftaleno acético (ANA) e 6-benzilaminopurina (BAP), sendo avaliados a multiplicação e o enraizamento. Foram testados diferentes substratos: S1 (Plantmax e vermiculita (1:1)); S2 (Plantmax e areia (1:1)) e S3 (pó de xaxim) na aclimatização e, posteriormente, o efeito dos tratamentos do cultivo in vitro: T1 (controle), T5 (2,5 ANA + 5 BAP) e T7 (5 ANA + 0 BAP), na aclimatização. $\mathrm{O}$ balanço favorável às citocininas promovido pelo tratamento T5 $(2,5 \mu \mathrm{M}$ ANA + $5 \mu \mathrm{M}$ BAP) promoveu maior número de brotos e de folhas em $B$. tuberculata. O maior comprimento das folhas, das raízes e maior número de raízes foi observado no tratamento T7 $(5 \mu \mathrm{M}$ ANA e $0 \mu \mathrm{M}$ BAP), favorável a auxina. Este tratamento apresentou efeito positivo com relação a aclimatização das plantas: T7 associado ao substrato S1, Plantmax e vermiculita (1:1) proporcionou melhores condições para a aclimatização das plântulas de $B$. tuberculata, propiciando maior número e comprimento das folhas, e elevada taxa de sobrevivência. 
PALAVRAS-CHAVE: Acido naftaleno acético. 6-benzilaminopurina. Cultura de tecidos. Estabelecimento in vitro. Substratos.

\section{REFERENCES}

BIELACH, A.; DUCLERCQ, J.; MARHAVÝ, P.; BENKOVÁ. E. Genetic approach towards the identification of auxin-cytokinin crosstalk components involved in root development. Biological sciences, v. 395, n. 1595, p. 1469-1478, 2012.

CASTRO, P. R. C.; SENA, J. O. A.; KLUGE, R. A. Introdução a fisiologia do desenvolvimento vegetal. Maringá: Eduem, 2002. p. 79-104.

COLOMBO, L. A.; FARIA, R. T.; ASSIS, A. M.; FONSECA, I. C. B. Aclimatização de um híbrido de Cattleya em substratos de origem vegetal sob dois sistemas de irrigação. Acta Scientiarum. Agronomy, v. 27, n. 1, p. 145-150, 2005.

COLOMBO, L. A.; FARIA, R. T.; CARVALHO, J. F. R. P.; ASSIS, A. M.; FONSECA, I. C. B. Influência do fungicida clorotalonil no desenvolvimento vegetativo e no enraizamento in vitro de duas espécies de orquídeas brasileiras. Acta Scientiarum. Agronomy, v. 26, n. 2, p. 253-258, 2004.

DEMATTÊ, J. B.; DEMATTÊ, M. E. S. P. Estudos hídricos com substratos vegetais para o cultivo de orquídeas epífitas. Pesquisa Agropecuária Brasileira, Embrapa, Rio de Janeiro, v. 31, v. 11, p. 803-808, 1996.

ERIG, A. C.; ROSSI, A. D.; FORTES, G. R. L. D. 6-Benzilaminopurina e ácido indolbutírico na multiplicação in vitro de amoreira-preta (Rubus idaeus L.), cv. Tupy. Ciência Rural, Santa Maria, v. 32, n. 5, p. 765-770, 2002. https://doi.org/10.1590/S0103-84782002000500005

FARIA, R. T.; SANTIAGO, D. C.; SARIDAKIS, D. P.; ALBINO, U. B.; ARAÚJO, R. Preservation of the brazilian orchid Cattleya walkeriana Gardner using in vitro propagation. Crop Breeding and Applied Biotechnology, v. 2, n.3, p. 489-492, 2002. https://doi.org/10.12702/1984-7033.v02n03a24

FERREIRA, W. M.; SUZUKI, R. M. O cultivo in vitro de orquídeas como alternativa para a preservação de espécies nativas ameaçadas de extinção. In: LOIOLA, M. I. B.; BASEIA, I. G.; LICHSTON, J. E. (Org.). Atualidades, Desafios e Perspectiva da Botânica no Brasil. Imagem Gráfica, Natal, 2008. p. 67-68.

GANTAIT. S.; MANDAL, N.; BHATTACHARYYA, S. P. K.; NANDY, S. Mass multiplication of Vanilla planifolia with pure genetic identity confirmed by ISSR. Journal of Plant Developmental Biology, v.3, n.1, p.18-23, 2009.

GIATTI, L.; LIMA, G. P. P. BAP (6-benzylaminopurine) in the regeneration in vitro of Blc Owen Holmes Ponkan x Brassavola digbiana $\mathrm{n}^{\circ}$ 2. Ciência e Agrotecnologia, Lavras, v. 31, n. 5, p. 1279-1285, 2007. https://doi.org/10.1590/S1413-70542007000500001

GRATTAPAGLIA, D.; MACHADO, M. A. Micropropagação. In: TORRES, A.C.; CALDAS, L. S.; BUSO, J. A. (Eds) Cultura de tecidos e transformação genética de plantas. Embrapa, Brasília, 1998. p. 183-260.

HERRMANN, M. H.; FREITAS, E. M. D. D.; PÉRICO, E. Cultivo in vitro de plântulas de orquídea em meio de cultura alternativo. Revista Brasileira Agrociencia, v. 17, n. 1-4, p. 162-166, 2011.

HOSSAIN, M. M. Asymbiotic seed germination and in vitro seedling development of Epidendrum ibaguense Kunth. (Orchidaceae). African Journal of Biotechnology, v. 7, n. 20, p. 3614-3619, 2008. 
HOSSAIN, M. M.; SHARMA, M.; PATHAK, P. Cost effective protocol for in vitro mass propagation of Cymbidium aloifolium (L.) Sw. - a medicinally important orchid. Engineering in Life Sciences, v. 9, n. 6, p. 110, 2009. https://doi.org/10.1002/elsc.200900015

HOSSAIN, M. M.; SHARMA, M.; TEIXEIRA, D. S. J. A.; PATHAK, P. Seed germination and tissue culture of Cymbidium giganteum Wall. ex Lindl. Scientia Horticulturae, v. 123, n. x, p. 479-487, 2010. https://doi.org/10.1016/j.scienta.2009.10.009

KRAUS, J. E.; KERBAUY, G. B.; MONTEIRO, W. R. Desenvolvimento de protocormos de Catasetum pileatum Rchb.f. in vitro: aspectos estruturais e conceituais. Hoehnea, v. 33, n. 2, p.177-184, 2006.

LASKOWSKI, M.; GRIENEISEN, V. A.; HOFHUIS, H.; COLETTE, A.; HOGEWEG, P.; MARÉE, A. F.; SCHERES, B. Root system architecture from coupling cell shape to auxin transport. PLOS Biol, v. 6, n. x, p. 2721-2735, 2008. https://doi.org/10.1371/journal.pbio.0060307

MENEGUCE, B.; OLIVEIRA, R. B. D.; FARIA, R. T. Propagação vegetativa de Epidendrum ibaguense Lindl. (Orchidaceae) em substratos alternativos ao xaxim. Semina: Ciências Agrárias, Londrina, v. 25, n. 2, p. 101106, 2004. http://dx.doi.org/10.5433/1679-0359.2004v25n2p101

MORAES, L. M. D.; DIAS, C. L. C.; FARIA, R. T. Substratos para aclimatização de plântulas de Dendrobium nobile Lindl. (Orchidaceae) propagadas in vitro. Acta Scientiarum. Agronomy, v. 24, n. 5, p. 1397-1400, 2002. https://doi.org/10.4025/actasciagron.v24i0.2429

MURASHIGE, T.; SKOOG, F. A. Revised medium for a rapid growth and biossays with tabacco tissue cultures. Physiologia Plantarum, v. 15, n. 3, p. 473-497, 1962. https://doi.org/10.1111/j.13993054.1962.tb08052.x

NAGARAJU, V.; PARTHASARATHY, V. A. In vitro micropropagation of Cymbidium giganteum. Indian Journal of Horticulture, Indian, v. 56, n. 36, p. 270-273, 1999.

NICIOLI, P. M.; PAIVA, R.; NOGUEIRA, R. C.; SANTANA, J. R. F. D.; SILVA, L. C.; SILVA, D. P. C. D.; PORTO, J. M. P. Ajuste do processo de micropropagação de barbatimão. Ciência Rural, Santa Maria, v. 38, n. 3, p. 685-689, 2008. https://doi.org/10.1590/S0103-84782008000300014

PARK, S. Y.; MURTHY, H. N.; PAEK, K. Y. Rapid propagation of Phalaenopsis from floral stalk-derived leaves. In Vitro Cellular \& Developmental Biology, v. 38, n. x , p. 168-172, 2002. https://doi.org/10.1079/IVP2001274

PATHAK, P.; MAHANT, K. C.; GUPTA, A. In vitro propagation as an aid to conservation and commercialization of Indian orchids: seed culture. In: PATHAK, P.; SEHGAL, R. N.; SHEKHAR, N.; SHARMA, M.; SOOD, A. (Eds) Orchids: Science and Commerce. Bishen Singh Mahendra Pal Singh, Dehra Dun, 2001. p. 319-362.

PIERIK, R. L. M.; STEEGMANS, H. H. M. The effect of 6-benzylaminopurine on growth and development of Cattleya seedlings grown from unripe seeds. Zeitschrift für Pflanzenphysiologie, v. 68, n. 3, p. 228-234, 1972. https://doi.org/10.1016/S0044-328X(72)80055-2

RASMUSSEN, H. N. Recent developments in the study of orchid mycorrhiza. Plant soil Netherlands, v. 244, n. 1, p. 149-163, 2002. https://doi.org/10.1023/A:1020246715436

ROBERTS, D. L.; DIXON, K. W. Orchids. Current Biology, v. 18, n, 8. p. 325-329, 2008. https://doi.org/10.1016/j.cub.2008.02.026 
SHIMURA, H.; KODA, Y. Micropropagation of Cypripedium macranthos var. rebunense through protocormlike bodies derived from mature seeds. Plant cell, tissue and organ culture, v. 78, n. 3, p. 273-276, 2004. https://doi.org/10.1023/B:TICU.0000025641.49000.b5

SORACE, M.; FARIA, R. T.; YAMAMOTO, L. Y.; SCHNITZER, J.; TAKAHASHI, L. S. A. Influência de auxina na aclimatização de Oncidium baueri (Orchidaceae). Semina: Ciências Agrárias, Londrina, v. 28, n. 2, p. 195-200, 2007. https://doi.org/10.5433/1679-0359.2007v28n2p195

TALUKDER, S. K.; NASIRUDDIN, K. M.; YASMIN, S.; HASSAN, L.; BEGUM, R. Shoot proliferation of Dendrobium orchid with BAP and ANA. Journal of Biological Sciences, v. 11, n. 11, p. 1058-1062, 2003.

The R Foundation for Statistical Computing Plataform. R Programan: A language and environment for statistical computing. R Foundation for Statistical Computing, Vienna. 2014.

UNEMOTO, L. K.; FARIA, R. T.; VIEIRA, A. O. S.; DALIO, R. J. D. Propagação in vitro de orquídeas brasileiras em meio de cultura simplificado. Revista Brasileira Agrociencias, Pelotas, v. 13, n. 2, p. 267-269, 2007. 